\title{
Phenolic compounds, organic acids and antioxidant activity of grape juices produced in industrial scale by different processes of maceration
}

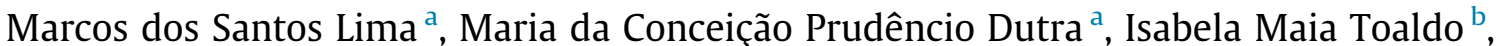 \\ Luiz Claudio Corrêa ${ }^{c}$, Giuliano Elias Pereira ${ }^{c}$, Débora de Oliveira ${ }^{\mathrm{d}}$, Marilde Terezinha Bordignon-Luiz ${ }^{\mathrm{b}}$, \\ Jorge Luiz Ninow ${ }^{\mathrm{d}, *}$ \\ ${ }^{a}$ Instituto Federal do Sertão Pernambucano, Campus Petrolina, Coordenação de Tecnologia em Alimentos, Jardim São Paulo 56314-520, Petrolina, PE, Brazil \\ ${ }^{\mathrm{b}}$ Universidade Federal de Santa Catarina, Departamento de Ciência e Tecnologia de Alimentos, Rod. Admar Gonzaga 1346, Itacorubi 88034-001, Florianópolis, SC, Brazil \\ ${ }^{\mathrm{c}}$ Empresa Brasileira de Pesquisa Agropecuária - Embrapa Semiárido/Uva e Vinho, Rodovia BR 428, Km 152, CP 23, CEP 56302-970 Petrolina, PE, Brazil \\ ${ }^{\mathrm{d}}$ Departamento de Engenharia Química e Engenharia de Alimentos, Universidade Federal de Santa Catarina (UFSC), Campus Universitário, Bairro Trindade, Caixa Postal \\ 476, Florianópolis, SC 88040-900, Brazil
}

\section{A R T I C L E I N F O}

\section{Article history:}

Received 7 January 2015

Received in revised form 4 April 2015

Accepted 6 April 2015

Available online 11 April 2015

\section{Keywords:}

Grape juice

Vitis labrusca $\mathrm{L}$.

Pectinases

Bioactive compounds

\begin{abstract}
A B S T R A C T
The effect of maceration process on the profile of phenolic compounds, organic acids composition and antioxidant activity of grape juices from new varieties of Vitis labrusca L. obtained in industrial scale was investigated. The extraction process presented a high yield without pressing the grapes. The use of a commercial pectinase resulted in an increase on extraction yield and procyanidins B1 and B2 concentrations and a decrease on turbidity and concentration of catechins. The combination of $60{ }^{\circ} \mathrm{C}$ and $3.0 \mathrm{~mL} 100 \mathrm{~kg}^{-1}$ of enzyme resulted in the highest extraction of phenolic compounds, reducing the content of acetic acid. The juices presented high antioxidant activity, related to the great concentration of malvidin, cyanidin, catechin and caffeic, cinnamic and gallic acids. Among the bioactive compounds, the juices presented high concentration of procyanidin B1, caffeic acid and trans-resveratrol, with higher levels compared to those reported in the literature.
\end{abstract}

(c) 2015 Elsevier Ltd. All rights reserved.

\section{Introduction}

The world consumption of grape juice has grown each year, being the Brazil and United States the largest producers and consumers (OIV, 2011). In Brazil, the production of juices has been spread in the region of Vale do Submédio São Francisco (VSF), located at the Northeast region. The main grape varieties for the juice production are Isabel Precoce (Vitis labrusca) and the hybrids BRS Cora and BRS Violeta, new Brazilian varieties for the production of juices of high quality (Lima et al., 2014).

The grape juice is a representative source of phenolic compounds and studies have demonstrated that the consumption of this beverage is associated to several health benefits to consumers (Krikorian et al., 2012; Vauzour, Rodriguez-Mateos, Corona, Oruna-Concha, \& Spencer, 2010). The phenolic compounds associated with these benefits are, mainly, flavonols, flavanols, anthocyanins, phenolic acids and stilbenes (Krikorian et al., 2012; Sautter et al., 2005; Xia, Deng, Guo, \& Li, 2010). Among the

\footnotetext{
* Corresponding author. Tel.: +55 483331 9448; fax: +55 4833319687

E-mail address: jorge@enq.ufsc.br (J.L. Ninow).
}

biological activities related to the phenolic compounds, the antioxidant activity is one of the main characteristics of grape juices (Burin et al., 2010; Dani et al., 2007; Dávalos, Bartolome, \& Gómez-Cordovés, 2005; Xia et al., 2010). Several factors exert influence on the juice composition, as the processing techniques (Morris \& Striegler, 2005). Among these, variables as temperature, maceration time and use of enzymes have influence on the analytical characteristics, phenolic compounds, antioxidant activity and yield of juices (Fuleki \& Ricardo-da-Silva, 2003; Leblanc, Johnson, \& Wilson, 2008; Mojsov, Ziberoski, \& Bozinovic, 2011; Talcott \& Lee, 2002).

In an industrial scale process, the techniques of juices production are divided basically in "Hot press" (HP) and "Cold press" $(\mathrm{CP})$, corresponding to the pressing the heated grape (HP) or pressing at ambient/chilling temperature (CP) (Morris, 1998; Morris \& Striegler, 2005). In the HP process the crushed grape is heated at $60-62{ }^{\circ} \mathrm{C}$, pectinase enzyme is added and samples are placed in stainless steel tanks with shaking to promote the extraction of compounds present in grape films, step known as maceration, for 30-60 min. Then, the juice is drained and the bagasse is pressed, obtaining a cloudy juice, which will be submitted to clarification 
treatments to remove suspended solids, using vacuum rotary filters or industrial centrifuges. After, the juice is stabilized, pasteurized and bottled hot (Iyer, Sacks, \& Padilla-Zakour, 2010; Morris, 1998).

In the CP process, the maceration of crushed grape is carried out at ambient/chilled temperature, with addition of sulfur dioxide to inhibit the action of oxidative enzymes, and addition of pectinases to degrade the structures of grape films, facilitating the liberation of phenolic compounds to the juice (Leblanc et al., 2008; Morris \& Striegler, 2005).

Another technique used is the "Hot Break" (HB), where the grapes are crushed and heated at temperatures higher than $75^{\circ} \mathrm{C}$, for a short time (5-10 min), to deactivate the polyphenoloxidases (PPO), and cooled at $60^{\circ} \mathrm{C}$ to add pectinase, following the procedures used in HP process (Iyer et al., 2010; Morris \& Striegler, 2005).

In the preparation of grape juices, the maceration process has relevant importance, since is in this phase where the incorporation of the compounds present on the grape film to the juice occurs, as phenolic compounds and aroma components (Fuleki \& Ricardo-da-Silva, 2003; Iyer et al., 2010). The heating of crushed grape has as objective to promote the plasmolysis of the membrane and ruptures on the fruit cell wall, facilitating the liberation of liquid and anthocyanins responsible for the color. The enzymes (pectinases) on the grape juices are used to hydrolyze the pectin present on the film, facilitating the liberation of shell compound; to reduce the viscosity of the juice and to increase the juice yield and also to reduce the turbidity (Cascales, Garcia, Roca, \& Plaza, 2012; Gomes, Guez, Martin, \& Silva, 2007). The addition of pectinases during the grape maceration can be considered a complex process, resulting in important alterations on the chemical composition of grape juice, mainly related to phenolic compounds. There are several commercial enzyme formulations available for application in fruit maceration, consisting of pectinases, cellulases and galactosidades (Arnous \& Meyer, 2010; Landbo \& Meyer, 2004).

The maceration process comprehends a critical step on grape juice production, directly related to the phenolic quality and bioactive properties of the product. Chemical modification as monomeric anthocyanins degradation and increase of phenolic acids concentration has been reported in grape derivatives treated with enzymatic pool based on pectinases and cellulase (Arnous \& Meyer, 2010; Toaldo et al., 2014). However, the chemical alterations from the grape maceration and their influence on grape juices processed in industrial scale are not yet known. In this context, the objective of this work was to evaluate the influence of maceration process at industrial conditions using a commercial enzymatic pool, based on pectinases, on the main group of phenolic compounds, organic acids and antioxidant activity of grape juices from new varieties of $V$. labrusca L.

\section{Materials and methods}

\subsection{Chemicals}

Trolox (6-hydroxy-2,5,7,8-tetramethylchroman-2-carboxylic acid), 2,2-azino-bis(3-ethylbenzthiazoline-6-sulfonic acid) (ABTS) and 2,2-diphenyl-1-picrylhydrazyl (DPPH) were purchased from Sigma-Aldrich (St. Louis, MO, USA). Ethanol, potassium persulfate and Folin-Ciocalteu reagent were obtained from Merck (Darmstadt, Germany). Methanol, acetonitrile and 85\% phosphoric acid were obtained from Vetec Ltda (Rio de Janeiro, Brazil), J.T. Baker (Phillipsburg, NJ, USA) and Fluka (Switzerland), respectively. Analytical standards of tartaric, malic, citric, succinic, lactic, acetic and ascorbic acids were purchased from Vetec Ltda (Rio de Janeiro, Brazil). Malvidin 3,5-diglucoside, cyanidin 3,5-diglucoside, malvidin 3-glucoside, cyanidin 3-glucoside, peonidin 3-glucoside, delphinidin 3-glucoside and pelargonidin 3-glucoside, kaempferol 3-glucoside, myricetin, quercetin, rutin (quercetin 3-rutinoside), isorhamnetin 3-glucoside, (+)-catechin, (-)-epicatechin, (-)-epicatechin gallate, (-)-epigallocatechin, procyanidins A2, B1 and B2, and trans-resveratrol were purchased from Extrasynthese (Genay, France). Gallic, cinnamic and caffeic acids were purchased from Chem Service (West Chester, USA). p-Coumaric and chlorogenic acids were obtained from Sigma-Aldrich (St. Louis, MO, USA). Ultra-pure water was obtained by purification using a Purelab Option Q Elga System (USA).

\subsection{Grape samples}

The grapes of Isabel Precoce and BRS Cora varieties were collected from a specific area destined to the production of commercial juice at Empresa Brasileira de Frutas Tropicais (EBFT/ASA), located at Projeto de Irrigação Senador Nilo Coelho - lote 07, PA III, Petrolina, Pernambuco State, Brazil, situated at $09^{\circ} 27^{\prime}$ S latitude and $40^{\circ} 38^{\prime} \mathrm{W}$ longitude, at an altitude of approximately $350 \mathrm{~m}$. The grape juices were produced in an industrial facility belonging to EBFT/ASA.

The plants were grown in vineyards with an average age of tree years, grafted on IAC 572 rootstock, planted in a field with 3.0 and 2.0 meters of spacing between lines and plants, respectively, and following a trellis system. The irrigation was by micro-aspersion and the vineyards were pruned (production pruning) on October and the grapes were harvested on February, when they reached the required standard maturation: soluble solids between 18 and $20{ }^{\circ}$ Brix, titratable acidity (TA) from 0.7 to $0.9 \mathrm{~g} 100 \mathrm{~mL}^{-1}$ of must, expressed as tartaric acid, and ${ }^{\circ} \mathrm{Brix} / \mathrm{TA}$ ratio between 20 and 25 .

The climatic data (average/month) for the region in the months of October and February, that is, from pruning to harvest time, were: temperature $28.4{ }^{\circ} \mathrm{C}$, rainfall $16.6 \mathrm{~mm}$, relative humidity $51.4 \%$, evaporation $9.1 \mathrm{~mm}$, luminance $546.3 \mathrm{~lx}$ /day and insolation $7.6 \mathrm{~h}$, measured at the weather station of Bebedouro (Petrolina, Pernambuco State, Brazil, $09^{\circ} 09^{\prime} \mathrm{S} 40^{\circ} 22^{\prime} \mathrm{W}$ ).

\subsection{Grape juice processing}

The juice was elaborated following the formulation adopted by industries of Northeast of Brazil, a mixture of Isabel Precoce $80 \%$ and BRS Cora $20 \%$, the cut (blend) was made by mixing the grapes at weighing. All juices were obtained by hot extraction without bagasse pressing, in an in-line system manufactured by JAPA ${ }^{\circledR}$ (Garibaldi, Rio Grande do Sul State, Brazil). The grapes were destemmed and crushed in an automatic equipment model DZ-35, with the addition of an enzymatic liquid mixture based on pectinase, called Endozym ${ }^{\circledR}$ Pectofruit PR, produced by Spindal - Pascal Biotech (Gretz-Armainvilliers, France) at doses of $0,1.5$ and $3.0 \mathrm{~mL} 100 \mathrm{~kg}^{-1}$ of fresh grapes. The grapes were then pumped into a maceration tank with controlled temperature and the mixture was heated at 50 and $60^{\circ} \mathrm{C}$ and held at this temperature for $1 \mathrm{~h}$ with constant pumping of the liquid. After maceration the juice was separated by draining, aided by a suction pump. This procedure did not require pressing of the bagasse. The juice was homogenized and then submitted to pasteurization at $85^{\circ} \mathrm{C}$ for $60 \mathrm{~s}$ in a tubular pasteurizer. The samples were then packaged, through hot filling of non-colored glass bottles of $300 \mathrm{~mL}$ capacity manufactured by Saint-Gobain ${ }^{\circledR}$ (São Paulo-SP, Brazil), using a gravimetric automatic filling machine (EVR12 model). The filled bottles were capped, closed and tumbled. The closed bottles were cooled in a cooling tunnel by water spraying until reaching an average temperature of $45^{\circ} \mathrm{C}$.

The juices were obtained by the following different maceration conditions: $50{ }^{\circ} \mathrm{C}$ without the addition of pectinase (T50E0), $60{ }^{\circ} \mathrm{C}$ 
without the addition of pectinase (T60E0), $50{ }^{\circ} \mathrm{C}$ with the addition of pectinase (1.5 mL $100 \mathrm{~kg}^{-1}$ of fresh grape) (T50E1.5), $60{ }^{\circ} \mathrm{C}$ with the addition of pectinase $\left(1.5 \mathrm{~mL} 100 \mathrm{~kg}^{-1}\right.$ of fresh grape (T60E1.5), $50{ }^{\circ} \mathrm{C}$ with addition of pectinase ( $3.0 \mathrm{~mL} 100 \mathrm{~kg}^{-1}$ of fresh grape) (T50E3) and $60^{\circ} \mathrm{C}$ with the addition of pectinase (3.0 $\mathrm{mL} 100 \mathrm{~kg}^{-1}$ of fresh grape) (T60E3).

\subsection{Determination of quality parameters of grape juice}

The analysis of juice quality was carried out by determining the pH (potentiometer pH Analyser - Tecnal (Brazil)); soluble solids ( ${ }^{\circ}$ Brix) (digital refractometer HI 96801 Hanna $^{\circledR}$, USA) and titratable acidity (TA), following the methodologies described in OIV, 2011. The color intensity was determined by obtaining the indices at 420,520 and $620 \mathrm{~nm}$ with a UV-Vis UV 2000A spectrophotometer, Instrutherm $^{\circledR}$ (Brazil), using glass cuvettes with a path length of $0.5 \mathrm{~cm}$ (OIV, 2011). The turbidity was measured by nephelometry using a turbidimeter Model HI 98703 Hanna $^{\circledR}$ (USA). The yield of juice was calculated by the volume (liters) obtained using $100 \mathrm{~kg}$ of fresh grape.

\subsection{Determination of total phenolics content, total monomeric anthocyanins and in vitro antioxidant activity of grape juice}

The total phenolics content of grape juices was determined using the Folin-Ciocalteu colorimetric method (Singleton \& Rossi, 1965). Briefly, grape juice samples were treated with saturated sodium carbonate solution, followed by the addition of the FolinCiocalteu reagent. The mixture was kept in dark at room temperature $\left(24^{\circ} \mathrm{C}\right)$ for $120 \mathrm{~min}$. Absorbance was determined at $765 \mathrm{~nm}$ on an UV-Vis L-2010 Hitachi ${ }^{\circledR}$ spectrometer (Tokyo, Japan). Gallic acid solutions were used for construction of calibration curve and results were expressed as $\mathrm{mg}$ of gallic acid equivalents (GAE)/L of grape juice.

The total monomeric anthocyanins content was determined using the pH-differential method, as described by Giusti and Wrolstad (2001). Grape juice samples were diluted with buffer solutions of $\mathrm{KCl}(0.025 \mathrm{M}) \mathrm{pH} 1.0$ and $\mathrm{CH}_{3} \mathrm{COONa}(0.4 \mathrm{M}) \mathrm{pH} 4.5$ and absorbance measurements were performed at 520 and $700 \mathrm{~nm}$, respectively. The total monomeric anthocyanins content was expressed as cyanidin-3-glucoside equivalents in $\mathrm{mg} \mathrm{L}^{-1}$ of grape juice.

The in vitro antioxidant activity was determined using the DPPH and ABTS radical scavenging methods, as described by Kim, Guo, and Packer (2002) and Re et al. (1999), respectively. Trolox was used as standard for the calibration curves and results were expressed as equivalents of Trolox per liter of grape juice (mM TEAC $\mathrm{L}^{-1}$ ). Absorbance measurements were performed on a UVVis L-2010 Hitachi $^{\circledR}$ spectrometer (Tokyo, Japan). For the analysis, solutions of DPPH and ABTS radicals were prepared in ethanol and diluted to an absorbance of $0.900 \pm 0.050$ and $0.700 \pm 0.030$, respectively. The antioxidant activity of grape juices was assessed through the rate of decay in absorbance at $517 \mathrm{~nm}$ for DPPH and at $754 \mathrm{~nm}$ for ABTS. In both procedures, absorbance of the radical solutions was determined before and after the addition of grape juice samples. In the DPPH method, absorbance was measured at time $t=0 \mathrm{~min}$ and at time $t=30 \mathrm{~min}$ after the addition of grape juice. In the ABTS method, absorbance was determined at time $t=0 \mathrm{~min}$ and at time $t=6 \mathrm{~min}$ after the addition of samples. All the analyses were performed in triplicates.

\subsection{Determination of organic acids of grape fruits}

The quantification of tartaric, malic, citric, lactic, succinic, acetic and ascorbic acids was carried out by High-Performance Liquid Chromatography (HPLC) using a WATERS (model Aliance e2695) chromatograph coupled with diode-array detection (DAD), following the methodology described by Rybka et al. (2012). The juice samples were filtered through a $0.45 \mu \mathrm{m}$ membrane and injected in triplicate. For the acid determination the DAD wavelength was maintained at $250 \mathrm{~nm}$ for ascorbic acid and $210 \mathrm{~nm}$ for tartaric, malic, citric, lactic, succinic and acetic acids, with a run time of

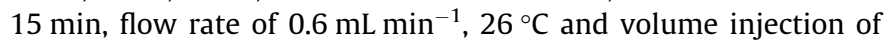
$10 \mu \mathrm{L}$. The column used was a Gemini-NX C18 $(150 \times 4.60 \mathrm{~mm}$, with $3 \mu \mathrm{m}$ internal particles) and the pre-column was a Gemini-NX C18 $(4.0 \times 3.0 \mathrm{~mm})$, both manufactured by Phenomenex ${ }^{\circledR}$. The liquid phase was comprised of a $0.025 \mathrm{M}$ solution of $\mathrm{KH}_{2} \mathrm{PO}_{4}$ acidified with $\mathrm{H}_{3} \mathrm{PO}_{4}$ until $\mathrm{pH}$ 2.6. The $R^{2}$ values obtained ranged from 0.9984 to 0.9998 . The lower and upper values for the limits of detection (LOD) were 0.03 and $3.59 \mathrm{mg} \mathrm{L}^{-1}$, respectively, for ascorbic and citric acids.

\subsection{Determination of individual phenolic compounds of grape juices}

The phenolic compounds were determined by HPLC on a WATERS chromatograph (model Aliance e2695), equipped with a quaternary solvent pump and automatic injector, coupled with DAD and fluorescence detection (FD), according to the methodology described by Natividade, Corrêa, Souza, Pereira, and Lima (2013). The data collection and analysis were carried out using the software Empower ${ }^{\mathrm{TM}} 2$ (Milford, EUA). In the DAD, the detection of compounds was performed at $220 \mathrm{~nm}$ for gallic acid, (-)-epicatechin gallate, (-)-epigallocatechin and procyanidin B1; $320 \mathrm{~nm}$ for $t$-resveratrol, caffeic acid, cinnamic acid, $p$-coumaric acid and chlorogenic acid; $360 \mathrm{~nm}$ for the flavonols kaempferol, myricetin, quercetin, rutin and isorhamnetin; and $520 \mathrm{~nm}$ for the anthocyanins malvidin 3,5-diglucoside, cyanidin 3,5-diglucoside, malvidin 3-glucoside, cyanidin 3-glucoside, peonidin 3-glucoside, delphinidin 3-glucoside and pelargonidin 3-glucoside. In the FD, the photon excitation was carried out at $280 \mathrm{~nm}$ and the emission at $320 \mathrm{~nm}$ for (+)-catechins, procyanidin B2, procyanidin $\mathrm{A} 2$ and (-)-epicatechin. The limit of detection ranged from 0.001 to $0.19 \mathrm{mg} \mathrm{L}^{-1}$ and the $R^{2}$ was always higher than 0.983 for all the assayed compounds.

The column used was a Gemini-NX C18, $150 \times 4.60 \mathrm{~mm}$, with $3 \mu \mathrm{m}$ internal particles, and the pre-column was a Gemini-NX $\mathrm{C} 18,4.0 \times 3.0 \mathrm{~mm}$, both manufactured by Phenomenex. The oven temperature was maintained at $40^{\circ} \mathrm{C}$, the injection volume was $10 \mu \mathrm{L}$ (juice previously filtered through a $0.45 \mu \mathrm{m}$ membrane; Allcrom-Phenomenex, USA) and the flow rate was $0.5 \mathrm{~mL} \mathrm{~min}{ }^{-1}$. The gradient used in the separation was $0 \mathrm{~min}: 100 \% \mathrm{~A} ; 10 \mathrm{~min}$ : 93\% $\mathrm{A}$ and $7 \% \mathrm{~B} ; 20 \mathrm{~min}: 90 \% \mathrm{~A}$ and $10 \% \mathrm{~B} ; 30 \mathrm{~min}: 88 \% \mathrm{~A}$ and 12\% B; 40 min: $77 \% \mathrm{~A}$ and $33 \% \mathrm{~B} ; 45 \mathrm{~min}: 65 \% \mathrm{~A}$ and $35 \% \mathrm{~B}$ and 55 min: $100 \% B$, where solvent $A$ is $0.85 \%$ phosphoric acid solution and solvent $\mathrm{B}$ is acetonitrile.

\subsection{Statistical analysis}

Six samples of juice produced by three repetitions were evaluated, each repetition composed by a process tank containing $3000 \mathrm{~kg}$ of grape fruit, totaling 18 tanks and $54,000 \mathrm{~kg}$ of grapes. The results obtained for the variables studied were subjected to analysis of variance (ANOVA) and followed by comparisons performed using the Tukey test with a probability of error of $5 \%$. The principal component analysis (PCA) was carried out to evaluate the relation among the different conditions of maceration employed and the main phenolic classes and antioxidant activity of the grape juice produced. The statistical analysis was carried out using the SPSS version 17.0 statistical package for Windows (SPSS, Chicago, USA). 
Table 1

Quality parameters of grape juices obtained in different conditions of maceration.

\begin{tabular}{|c|c|c|c|c|c|c|}
\hline \multirow{2}{*}{$\begin{array}{l}\text { Temperature } \\
\text { Enzyme dose }\end{array}$} & \multicolumn{3}{|l|}{$50^{\circ} \mathrm{C}$} & \multicolumn{3}{|l|}{$60{ }^{\circ} \mathrm{C}$} \\
\hline & 0 & 1.5 & 3.0 & 0 & 1.5 & 3.0 \\
\hline $\mathrm{pH}$ & $3.39 \pm 0.2 \mathrm{a}$ & $3.38 \pm 0.01 \mathrm{a}$ & $3.37 \pm 0.04 \mathrm{a}$ & $3.39 \pm 0.07 \mathrm{a}$ & $3.39 \pm 0.08 \mathrm{a}$ & $3.35 \pm 0.02 a$ \\
\hline Soluble solids ( ${ }^{\circ}$ Brix) & $19.2 \pm 0.2 \mathrm{a}$ & $19.0 \pm 0.4 \mathrm{a}$ & $19.2 \pm 0.1 \mathrm{a}$ & $19.2 \pm 0.3 \mathrm{a}$ & $18.7 \pm 0.6 \mathrm{a}$ & $19.2 \pm 0.0 \mathrm{a}$ \\
\hline Titratable acidity (TA) & $0.83 \pm 0.02 a$ & $0.85 \pm 0.04 \mathrm{a}$ & $0.84 \pm 0.02 a$ & $0.85 \pm 0.04 \mathrm{a}$ & $0.85 \pm 0.04 \mathrm{a}$ & $0.85 \pm 0.03 a$ \\
\hline${ }^{\circ}$ Brix/TA & $23.2 \pm 0.9 \mathrm{a}$ & $22.5 \pm 0.8 \mathrm{a}$ & $22.9 \pm 0.7 \mathrm{a}$ & $22.6 \pm 0.9 \mathrm{a}$ & $22.2 \pm 1.9 \mathrm{a}$ & $22.8 \pm 0.9 \mathrm{a}$ \\
\hline Turbidity (NTU) & $147 \pm 6 a$ & $113 \pm 5 b c$ & $100 \pm 5 \mathrm{~cd}$ & $135 \pm 15 \mathrm{ab}$ & $100 \pm 9 \mathrm{~cd}$ & $84 \pm 15 \mathrm{e}$ \\
\hline Color intensity & $6.56 \pm 1.04 \mathrm{a}$ & $6.00 \pm 0.51 \mathrm{a}$ & $5.78 \pm 0.39 a$ & $5.38 \pm 0.43 \mathrm{a}$ & $5.94 \pm 0.29 \mathrm{a}$ & $5.77 \pm 0.44 a$ \\
\hline$\%$ juice yield & $59 \pm 0.6 c$ & $64.1 \pm 0.1 \mathrm{~b}$ & $64.7 \pm 0.3 \mathrm{ab}$ & $59 \pm 0.4 \mathrm{c}$ & $64.1 \pm 0.3 \mathrm{~b}$ & $65 \pm 0.2 \mathrm{a}$ \\
\hline
\end{tabular}

Means followed by the same letters in the same lines do not differ by Tukey test at $5 \%$ probability.

Dose of enzyme as mL $100 \mathrm{~kg}^{-1}$ of grape fruit; TA - as g $100 \mathrm{~mL}^{-1}$ tartaric acid; SS - \% ( ${ }^{\circ}$ Brix); NTU - nephelometric turbidity units.

Table 2

Mean values of organic acids of grape juices obtained in different conditions of maceration.

\begin{tabular}{|c|c|c|c|c|c|c|}
\hline \multirow{2}{*}{$\begin{array}{l}\text { Temperature } \\
\text { Enzyme dose }\end{array}$} & \multicolumn{3}{|l|}{$50^{\circ} \mathrm{C}$} & \multicolumn{3}{|l|}{$60^{\circ} \mathrm{C}$} \\
\hline & 0 & 1.5 & 3.0 & 0 & 1.5 & 3.0 \\
\hline \multicolumn{7}{|l|}{ Organic acids } \\
\hline Tartaric $\left(\mathrm{g} \mathrm{L}^{-1}\right)$ & $5.64 \pm 0.22 \mathrm{a}$ & $5.32 \pm 0.47 \mathrm{ab}$ & $4.75 \pm 0.56 \mathrm{ab}$ & $5.33 \pm 0.29 a b$ & $5.26 \pm 0.41 \mathrm{ab}$ & $4.30 \pm 0.19 b$ \\
\hline Malic $\left(\mathrm{g} \mathrm{L}^{-1}\right)$ & $3.46 \pm 0.18 b$ & $3.65 \pm 0.04 \mathrm{ab}$ & $3.77 \pm 0.02 \mathrm{ab}$ & $3.50 \pm 0.06 \mathrm{ab}$ & $3.80 \pm 0.03 a$ & $3.70 \pm 0.21 \mathrm{ab}$ \\
\hline Citric $\left(\mathrm{mg} \mathrm{L}^{-1}\right)$ & $313 \pm 6 b$ & $290 \pm 35 b$ & $470 \pm 26 \mathrm{a}$ & $317 \pm 6 b$ & $345 \pm 40 \mathrm{~b}$ & $503 \pm 30 \mathrm{a}$ \\
\hline Ascorbic $\left(\mathrm{mg} \mathrm{L}^{-1}\right)$ & $8.3 \pm 3.2 \mathrm{a}$ & $11 \pm 0.3 \mathrm{a}$ & $9.6 \pm 0.6 \mathrm{a}$ & $9.2 \pm 1.0 \mathrm{a}$ & $9.4 \pm 0.4 \mathrm{a}$ & $9.6 \pm 0.2 \mathrm{a}$ \\
\hline Lactic $\left(\mathrm{mg} \mathrm{L}^{-1}\right)$ & $227 \pm 46 \mathrm{bc}$ & $373 \pm 97 \mathrm{abc}$ & $603 \pm 227 \mathrm{ab}$ & $200 \pm 10 c$ & $693 \pm 237 a$ & $278 \pm 6$ bc \\
\hline Succinic $\left(\mathrm{mg} \mathrm{L}^{-1}\right)$ & $87 \pm 25 a$ & $73 \pm 15 a$ & $70 \pm 20 \mathrm{a}$ & $43 \pm 15$ a & $87 \pm 6$ a & $80 \pm 72 a$ \\
\hline Acetic $\left(\mathrm{mg} \mathrm{L}^{-1}\right)$ & $537 \pm 58 a b$ & $510 \pm 70 \mathrm{ab}$ & $420 \pm 10 b$ & $637 \pm 55 a$ & $450 \pm 17 b$ & $460 \pm 121 \mathrm{ab}$ \\
\hline Total organic acids $\left(\mathrm{g} \mathrm{L}^{-1}\right)$ & $10.27 \pm 0.54$ & $10.23 \pm 0.73$ & $10.09 \pm 0.86$ & $10.07 \pm 0.44$ & $10.64 \pm 0.74$ & $9.33 \pm 0.63$ \\
\hline
\end{tabular}

Means followed by the same letters in the same lines do not differ by Tukey test at $5 \%$ probability.

Dose of enzyme as mL $100 \mathrm{~kg}^{-1}$ of grape fruit.

\section{Results and discussion}

\subsection{Grape juice quality}

The results for quality physico-chemical analyses of grape juices are presented in Table 1 . The maceration conditions did not influence the soluble solid (SS) content, $\mathrm{pH}$, titratable acidity (TA) and SS/TA ratio. All the values are in accordance with the Brazilian regulation for integral juice: $14{ }^{\circ}$ Brix (minimum for SS), minimum of

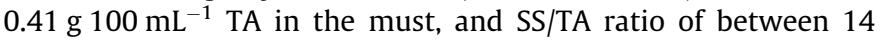
and 45 (Brazil, 2000). The mean values for the SS content $(19.1 \pm 0.4)$ in the juices were higher than that obtained by Rizzon and Miele (2012) for commercial Brazilian juices (16.2 \pm 1.1 ).

The color intensity also presented no significant difference among the maceration conditions tested, with mean values from 5.38 to 6.56, according to Brazilian grape juices (Burin et al., 2010; Rizzon \& Miele, 2012). The values of turbidity varied from 84 to 147 NTU, decreasing with the increase of enzyme dose and maceration temperature. Temperature did not influence the juice yield, but the use of pectinases enhanced the yield from $59 \%$ to $65 \%$ (liters of juice per ton of grape fruit), using $3.0 \mathrm{~mL} 100 \mathrm{~kg}^{-1}$ of grape. According to Morris (1998) the yield of grape juice can reach $73.8 \%$ (HP process) and 64.3\% (CP process), depending on the cultivar of fruit and efficiency of pressing. Leblanc et al. (2008) obtained an increase on juice yield from $41.5 \%$ to $61.1 \%$ (grape "Carlos") and from $40.8 \%$ to $56.2 \%$ (grape "Noble") by the addition of $10 \mathrm{~g}$ pectinase per $100 \mathrm{~kg}$ of fruit, after $14 \mathrm{~h}$ of maceration at $7{ }^{\circ} \mathrm{C}$. The same authors reached a yield from $49 \%$ to $52 \%$ for the same cultivars in HP process at $60{ }^{\circ} \mathrm{C}$ without the addition of enzyme. Mojsov et al. (2011) obtained yields from 44.8\% (with-

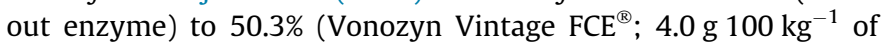
grape) for grapes cultivar "Vranec" by cold pressing, in industrial scale process.

The decrease of turbidity with increase of enzyme content can be associated with the degradation of soluble pectin and other polysaccharides presents in the juice by pectinases. These compounds can act as colloids, increasing the turbidity of the juice (Arnous \& Meyer, 2010; Landbo \& Meyer, 2004).

The results obtained in the present work demonstrate that the methodology for production of grape juice presented here led to good yields because even without the addition of enzyme a yield of $59 \%$ was obtained, which can be considered high compared to the works form the literature. The yields with addition of enzyme increased about 5\%, and are in accordance with other works (Morris, 1998; Mojsov et al., 2011). An enzyme dose of $1.5 \mathrm{~mL} 100 \mathrm{~kg}^{-1}$ of grape showed a yield of $67 \%$, considered good since the manufacturer recommendation is the use of a dose from 2.0 to $4.0 \mathrm{~mL} 100 \mathrm{~kg}^{-1}$ for grapes maceration.

\subsection{Content of organic acids of grape juices}

The content of organic acids for the different formulations of grape juice is presented in Table 2. The tested maceration treatments resulted in significant differences on the composition of organic acids. For tartaric acid, the main organic acid of grapes and derivatives, it was observed a decrease with the treatment of $60{ }^{\circ} \mathrm{C}$ with addition of $3.0 \mathrm{~mL}$ of enzyme, compared to that obtained at $50{ }^{\circ} \mathrm{C}$ without addition of enzyme. The mean values varied from 5.64 to $4.30 \mathrm{~g} \mathrm{~L}^{-1}$. Citric acid content did not varied significantly in treatments without and with the addition of $1.5 \mathrm{~mL}$ of enzyme, but compared to the formulation obtained with the addition of $3.0 \mathrm{~mL}$ of enzyme a considerable increase on the concentration of this acid was observed, from 290 to $503 \mathrm{mg} \mathrm{L}^{-1}$. The contents of succinic and ascorbic acids on grape juices did not were influenced by the maceration treatments employed and presented mean values from 43 to $87 \mathrm{mg} \mathrm{L}^{-1}$, and 8.3 to $11.0 \mathrm{mg} \mathrm{L}^{-1}$, respectively.

In a general way, the content of lactic acid in the juice increased with the addition of enzyme. Acetic acid, the most undesirable acid in juices and wines, presented a significant reduction using 
Table 3

Phenolics compounds of grape juices obtained in different conditions of maceration.

\begin{tabular}{|c|c|c|c|c|c|c|}
\hline \multirow{2}{*}{$\begin{array}{l}\text { Temperature } \\
\text { Enzyme dose }\end{array}$} & \multicolumn{3}{|l|}{$50{ }^{\circ} \mathrm{C}$} & \multicolumn{3}{|l|}{$60^{\circ} \mathrm{C}$} \\
\hline & 0 & 1.5 & 3.0 & 0 & 1.5 & 3.0 \\
\hline \multicolumn{7}{|l|}{ Flavanols } \\
\hline$(+)$-Catechin & $48.1 \pm 13.4 \mathrm{a}$ & $9.8 \pm 0.9 b$ & $9.9 \pm 0.5 b$ & $50.8 \pm 4.7 \mathrm{a}$ & $14.9 \pm 0.6 b$ & $11.2 \pm 3.4 \mathrm{~b}$ \\
\hline (-)-Epicatechin & $1.0 \pm 1.0 \mathrm{a}$ & $0.6 \pm 0.1 \mathrm{a}$ & $0.8 \pm 0.7 \mathrm{a}$ & $1.4 \pm 0.5 \mathrm{a}$ & $1.3 \pm 0.1 \mathrm{a}$ & $1.7 \pm 0.3 \mathrm{a}$ \\
\hline (-)-Epicatechin gallate & $1.6 \pm 0.1 \mathrm{a}$ & $1.4 \pm 0.1 \mathrm{a}$ & $2.2 \pm 1.2 \mathrm{a}$ & $2.4 \pm 3.0 \mathrm{a}$ & $0.8 \pm 0.0 \mathrm{a}$ & $0.8 \pm 0.1 \mathrm{a}$ \\
\hline (-)-Epigallocatechin gallate & $1.4 \pm 0.6 \mathrm{a}$ & $3.1 \pm 0.4 \mathrm{a}$ & $2.1 \pm 0.5 \mathrm{a}$ & $5.0 \pm 1.1 \mathrm{a}$ & $3.9 \pm 0.6 \mathrm{a}$ & $1.8 \pm 0.3 \mathrm{a}$ \\
\hline Procyanidin A2 & $2.8 \pm 0.1 \mathrm{a}$ & $2.8 \pm 0.2 \mathrm{a}$ & $2.6 \pm 0.2 \mathrm{a}$ & $2.6 \pm 0.3 \mathrm{a}$ & $3.2 \pm 0.7 \mathrm{a}$ & $3.0 \pm 0.2 \mathrm{a}$ \\
\hline Procyanidin B1 & $5.9 \pm 5.5 \mathrm{~b}$ & $7.3 \pm 0.5 b$ & $34.4 \pm 2.4 \mathrm{a}$ & $11.6 \pm 2.8 b$ & $9.9 \pm 1.0 \mathrm{~b}$ & $36.8 \pm 0.8 \mathrm{a}$ \\
\hline Procyanidin B2 & $9.3 \pm 0.4 b$ & $9.0 \pm 1.5 \mathrm{~b}$ & $13.1 \pm 3.1 \mathrm{ab}$ & $11.3 \pm 0.9 \mathrm{ab}$ & $10.4 \pm 0.6 \mathrm{~b}$ & $16.1 \pm 2.5 \mathrm{a}$ \\
\hline Total Flavanols quantification & $70.1 \pm 21.1$ & $34 \pm 3.7$ & $65.1 \pm 8.6$ & $109.7 \pm 13.3$ & $44.4 \pm 3.6$ & $71.4 \pm 7.6$ \\
\hline \multicolumn{7}{|l|}{ Flavonols } \\
\hline Kaempferol & $0.7 \pm 0.5 \mathrm{~b}$ & $1.4 \pm 0.4 \mathrm{ab}$ & $0.9 \pm 0.2 \mathrm{ab}$ & $1.5 \pm 0.3 \mathrm{a}$ & $1.0 \pm 0.1 \mathrm{ab}$ & $1.2 \pm 0.2 \mathrm{ab}$ \\
\hline Myricetin & $0.1 \pm 0.1 \mathrm{a}$ & $0.2 \pm 0.0 \mathrm{a}$ & $0.2 \pm 0.1 \mathrm{a}$ & $0.2 \pm 0.1 \mathrm{a}$ & $0.2 \pm 0.1 \mathrm{a}$ & $0.3 \pm 0.1 \mathrm{a}$ \\
\hline Isorhamnetin & $0.8 \pm 0.6 \mathrm{a}$ & $1.3 \pm 0.2 \mathrm{a}$ & $1.2 \pm 0.6 \mathrm{a}$ & $1.5 \pm 0.2 \mathrm{a}$ & $1.4 \pm 0.3 \mathrm{a}$ & $1.6 \pm 0.2 \mathrm{a}$ \\
\hline Rutin & $0.9 \pm 0.6 \mathrm{~b}$ & $1.4 \pm 0.2 \mathrm{ab}$ & $1.5 \pm 0.1 \mathrm{ab}$ & $1.5 \pm 0.1 \mathrm{ab}$ & $1.4 \pm 0.3 \mathrm{ab}$ & $1.8 \pm 0.3 \mathrm{a}$ \\
\hline Quercetin & $0.01 \pm 0.01 \mathrm{c}$ & $0.03 \pm 0.06 \mathrm{~b}$ & $0.10 \pm 0.00 \mathrm{ab}$ & $0.10 \pm 0.00 \mathrm{ab}$ & $0.07 \pm 0.06 \mathrm{ab}$ & $0.17 \pm 0.06 \mathrm{a}$ \\
\hline Total flavonols quantification & $2.7 \pm 1.8$ & $4.3 \pm 1.5$ & $3.9 \pm 1.0$ & $4.8 \pm 0.7$ & $4.1 \pm 0.9$ & $5.1 \pm 0.9$ \\
\hline \multicolumn{7}{|l|}{ Stilbene } \\
\hline trans-Resveratrol & $0.67 \pm 0.1 \mathrm{a}$ & $0.67 \pm 0.1 \mathrm{a}$ & $0.90 \pm 0.3 \mathrm{a}$ & $0.70 \pm 0.1 \mathrm{a}$ & $0.73 \pm 0.1 \mathrm{a}$ & $0.90 \pm 0.4 \mathrm{a}$ \\
\hline \multicolumn{7}{|l|}{ Anthocyanins } \\
\hline Malvidin 3,5-diglucoside & $6.6 \pm 2.0 \mathrm{a}$ & $4.6 \pm 0.6 \mathrm{a}$ & $5.2 \pm 1.0 \mathrm{a}$ & $5.6 \pm 0.6 \mathrm{a}$ & $6.1 \pm 0.3 \mathrm{a}$ & $6.4 \pm 0.1 \mathrm{a}$ \\
\hline Malvidin 3-glucoside & $11.0 \pm 4.9 \mathrm{a}$ & $7.1 \pm 0.8 \mathrm{a}$ & $8.1 \pm 3.6 \mathrm{a}$ & $8.8 \pm 1.5 \mathrm{a}$ & $10.5 \pm 0.5 \mathrm{a}$ & $11.2 \pm 0.5 \mathrm{a}$ \\
\hline Cyanidin-3,5-diglucoside & $5.6 \pm 0.9 \mathrm{a}$ & $3.9 \pm 1.0 \mathrm{a}$ & $4.8 \pm 1.0 \mathrm{a}$ & $4.7 \pm 0.5 \mathrm{a}$ & $5.7 \pm 0.3 \mathrm{a}$ & $5.6 \pm 1.0 \mathrm{a}$ \\
\hline Cyanidin 3-glucoside & $7.9 \pm 1.9 \mathrm{a}$ & $5.8 \pm 1.2 \mathrm{a}$ & $5.2 \pm 3.2 \mathrm{a}$ & $6.6 \pm 0.4 \mathrm{a}$ & $7.3 \pm 0.3 \mathrm{a}$ & $8.0 \pm 0.3 \mathrm{a}$ \\
\hline Delphinidin 3-glucoside & $6.0 \pm 3.5 \mathrm{a}$ & $1.2 \pm 0.3 \mathrm{a}$ & $3.3 \pm 2.8 \mathrm{a}$ & $4.6 \pm 1.7 \mathrm{a}$ & $5.7 \pm 1.5 \mathrm{a}$ & $6.0 \pm 1.2 \mathrm{a}$ \\
\hline Peonidin 3-glucoside & $3.1 \pm 1.5 \mathrm{a}$ & $2.0 \pm 0.1 \mathrm{a}$ & $2.2 \pm 1.0 \mathrm{a}$ & $2.4 \pm 0.4 \mathrm{a}$ & $2.4 \pm 0.2 \mathrm{a}$ & $3.0 \pm 0.1 \mathrm{a}$ \\
\hline Pelargonidin 3-glucoside & $3.9 \pm 1.9 \mathrm{a}$ & $0.4 \pm 0.2 \mathrm{a}$ & $2.4 \pm 1.4 \mathrm{a}$ & $2.5 \pm 1.3 \mathrm{a}$ & $3.5 \pm 0.4 \mathrm{a}$ & $3.6 \pm 0.4 \mathrm{a}$ \\
\hline Total anthocyanins quantification & $44.1 \pm 16.6$ & $25 \pm 4.2$ & $31.2 \pm 14$ & $35.2 \pm 6.4$ & $41.2 \pm 3.5$ & $43.8 \pm 3.6$ \\
\hline \multicolumn{7}{|l|}{ Phenolics acids } \\
\hline Gallic acid & $2.7 \pm 0.7 \mathrm{a}$ & $2.2 \pm 0.1 \mathrm{a}$ & $2.3 \pm 0.4 \mathrm{a}$ & $3.4 \pm 1.1 \mathrm{a}$ & $2.8 \pm 0.3 \mathrm{a}$ & $2.8 \pm 0.5 \mathrm{a}$ \\
\hline Caffeic acid & $17.9 \pm 1.6 \mathrm{a}$ & $15.3 \pm 0.2 \mathrm{a}$ & $15.7 \pm 1.0 \mathrm{a}$ & $16.5 \pm 1.1 \mathrm{a}$ & $17.2 \pm 0.9 \mathrm{a}$ & $17.2 \pm 1.6 \mathrm{a}$ \\
\hline Cinnamic acid & $1.2 \pm 1.0 \mathrm{a}$ & $0.5 \pm 0.1 \mathrm{a}$ & $1.2 \pm 0.7 \mathrm{a}$ & $1.4 \pm 0.8 \mathrm{a}$ & $1.7 \pm 0.3 \mathrm{a}$ & $2.0 \pm 0.2 \mathrm{a}$ \\
\hline Chlorogenic acid & $1.8 \pm 0.4 \mathrm{a}$ & $3.2 \pm 2.0 \mathrm{a}$ & $2.3 \pm 0.1 \mathrm{a}$ & $2.4 \pm 1.2 \mathrm{a}$ & $2.7 \pm 0.1 \mathrm{a}$ & $2.5 \pm 0.3 \mathrm{a}$ \\
\hline$p$-Coumaric acid & $1.1 \pm 0.4 \mathrm{~b}$ & $1.4 \pm 0.1 \mathrm{ab}$ & $1.4 \pm 0.0 \mathrm{ab}$ & $1.5 \pm 0.5 \mathrm{ab}$ & $1.6 \pm 0.2 \mathrm{ab}$ & $1.7 \pm 0.1 \mathrm{a}$ \\
\hline Total phenolics acids quantification & $24.7 \pm 4.1$ & $22.4 \pm 2.5$ & $22.9 \pm 2.2$ & $29.2 \pm 4.7$ & $26 \pm 1.8$ & $26.2 \pm 2.7$ \\
\hline Total monomeric anthocyanins ${ }^{\dagger}$ & $155 \pm 46 a$ & $107 \pm 22 \mathrm{a}$ & $117 \pm 39 a$ & $123 \pm 2 \mathrm{a}$ & $103 \pm 6 a$ & $129 \pm 21 \mathrm{a}$ \\
\hline Total phenolics ${ }^{\S}$ & $1343 \pm 218 \mathrm{ab}$ & $959 \pm 33 b$ & $1088 \pm 183 a b$ & $1296 \pm 39 a b$ & $1384 \pm 207 \mathrm{a}$ & $1203 \pm 101 \mathrm{ab}$ \\
\hline
\end{tabular}

Means followed by the same letters in the same lines do not differ by Tukey test at $5 \%$ probability.

Dose of enzyme as $\mathrm{mL} 100 \mathrm{~kg}^{-1}$ of grape fruit.

$\dagger$ Total monomeric anthocyanins quantified by the technic of difference of $\mathrm{pH}$ and expressed as equivalent to cyanidin 3-glucoside.

$\S$ Total phenolics measured with Folin-Ciocalteu expressed as $\mathrm{mg} \mathrm{L}^{-1}$ equivalent to gallic acid.

pectinase, from 637 to $420 \mathrm{mg} \mathrm{L}^{-1}$. The content of tartaric and malic acids obtained here are in accordance with the literature for Brazilian grape juices (Lima et al., 2014; Rizzon \& Miele, 2012) and also juices of different cultivars of Vitis vinífera obtained by CP process (Soyer, Koca, \& Karadeniz, 2003). The citric acid content obtained presented values higher than the specific literature, where the contents vary from 31 to $181 \mathrm{mg} \mathrm{L}^{-1}$ (Soyer et al., 2003).

\subsection{Content of total phenolics and flavanol compounds of grape juices}

The results for phenolics compounds quantified in grape juices are presented in Table 3. The mean values of total phenolics varied from 959 to $1384 \mathrm{mg} \mathrm{L}^{-1}$ in the different samples of juice obtained in the present work. The concentration of total phenolics was similar among the treatments, with a low value for the juice obtained in experiment T50E1.5. The values of total phenolics obtained here are in agreement with results from the literature for commercial Brazilian grape fruits (270-3433 $\mathrm{mg} \mathrm{L}^{-1}$, with mean values among 1430 and $1915 \mathrm{mg} \mathrm{L}^{-1}$ ) (Burin et al., 2010; Malacrida \& Motta, 2005; Sautter et al., 2005). The results were also similar to commercial Spanish juices (mean values from 705 to $1177 \mathrm{mg} \mathrm{L}^{-1}$ ) (Dávalos et al., 2005; Moreno-Montoro, Olalla-Herrera, Gimenez-Martinez, Navarro-Alarcon, \& Rufián-Henares, 2015).
For the flavanols epicatechin, epicatechin gallate, epigallocatechin and procyanidin $\mathrm{A} 2$, no significant differences were observed for different maceration treatments. Temperatures of 50 and $60{ }^{\circ} \mathrm{C}$ did not show influence on catechin concentration, but the treatments without the addition of enzyme (T50E0 and T60E0) presented higher contents of catechin, with mean values from 48.1 to $50.8 \mathrm{mg} \mathrm{L}^{-1}$, related to the juices with doses of 1.5 and $3.0 \mathrm{~mL}$ of enzyme (T50E1.5, T50E3, T60E1.5 and T60E3), with mean values from 9.8 to $14.9 \mathrm{mg} \mathrm{L}^{-1}$. Procyanidins B1 and B2 contents did not differ among the treatments T50E0, T60E0, T50E1.5 and T60E1.5; but using $3.0 \mathrm{~mL}$ of enzyme (T50E3 and T60E3) the concentration of these compounds presented a significant increase, mainly for procyanidin B1 (from 5.9 and 11.6 to 34.4 and $36.8 \mathrm{mg} \mathrm{L}^{-1}$ ), respectively. The main flavanols found in the juices were catechin and procyanidins B1 and B2, compounds directly associated with high antioxidant activities (Muselík, García-Alonso, Martín-López, Žemlička, \& Rivas-Gonzalo, 2007). The work by Fuleki and Ricardo-da-Silva (2003) with Concord grape juice obtained by HP process and addition of pectinase $50 \mathrm{mg} \mathrm{L}^{-1}$ and maceration at $60{ }^{\circ} \mathrm{C}$ presented flavanols contents similar to those obtained in our work. These authors also observed that the pasteurization step enhanced the concentration of procyanidins B1 and B2. Mean values of flavanols quantified by HPLC on juices produced here varied 


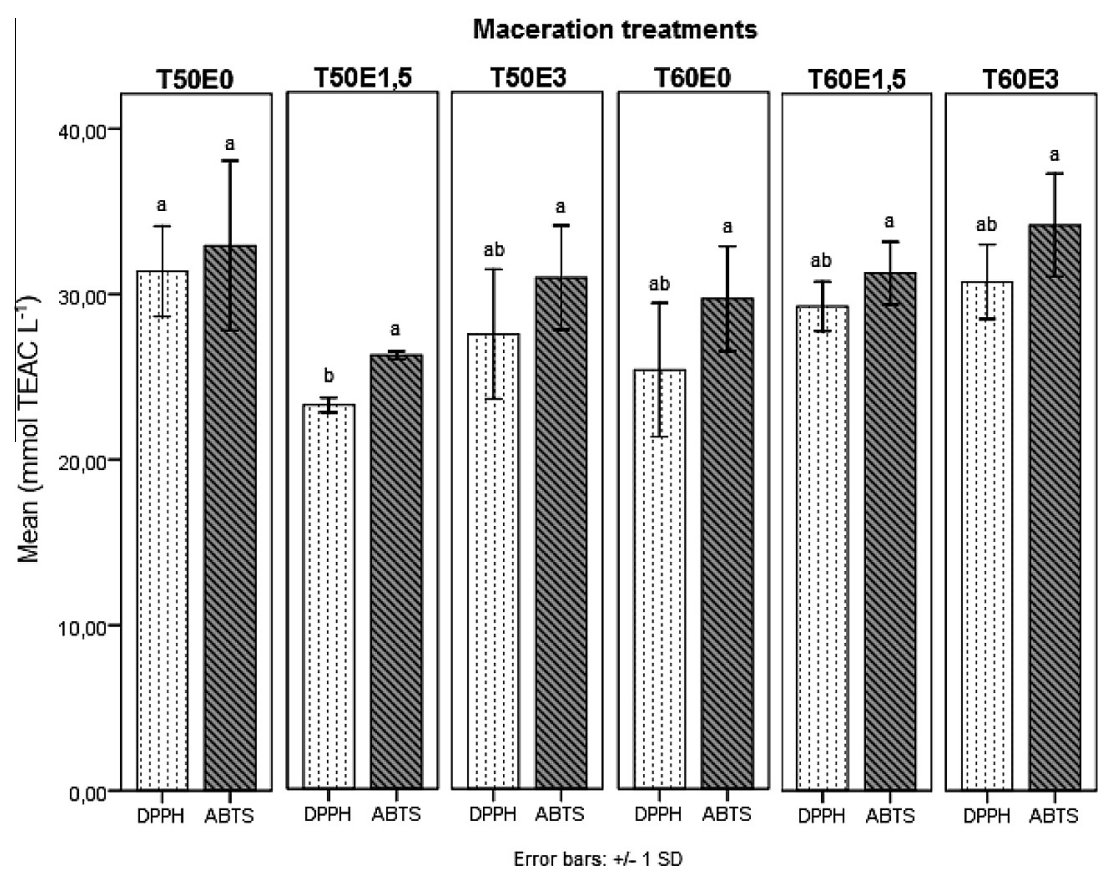

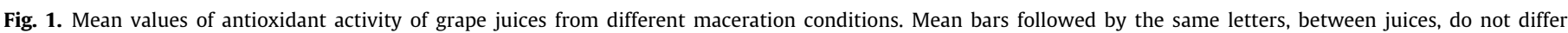

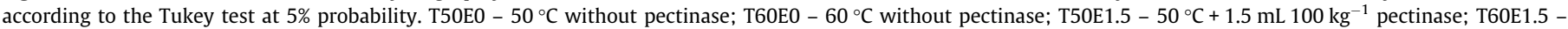
$60{ }^{\circ} \mathrm{C}+1.5 \mathrm{~mL} 100 \mathrm{~kg}^{-1}$ pectinase; T50E3 $-50{ }^{\circ} \mathrm{C}+3.0 \mathrm{~mL} 100 \mathrm{~kg}^{-1}$ pectinase and T60E3 $-60{ }^{\circ} \mathrm{C}+3.0 \mathrm{~mL} 100 \mathrm{~kg}^{-1}$ pectinase.

from 34 to $109.7 \mathrm{mg} \mathrm{L}^{-1}$, higher than those mentioned by Moreno-Montoro et al. (2015) for Spanish grape juices, with mean reported values of 0.53 and $3.07 \mathrm{mg} \mathrm{L}^{-1}$, for white and red juices, respectively.

The total quantified flavanols decreased in the treatments with $1.5 \mathrm{~mL} \mathrm{~kg}^{-1}$ of enzyme (T50E1.5 and T60E1.5) compared to the treatments without enzyme (T50E0 and T60E0) and those using $3.0 \mathrm{~mL} \mathrm{~kg}^{-1}$ (T50E3 and T60E3). In the first case (without enzyme) due to the presence of higher concentrations of catechins, and, in the second case ( $3.0 \mathrm{~mL} \mathrm{~kg}^{-1}$ of enzyme dose) by the higher extraction of compounds as procyanidins B1 and B2.

\subsection{Content of flavonols and trans-resveratrol of grape juices}

The flavonols content presented significant difference only for the juice obtained in the experimental condition T50E0, with lower values of kaempferol, quercetin and rutin. The other conditions of maceration did not influence significantly the flavanols quantified. The sum of flavanols (kaempferol, isorhamnetin, quercetin, rutin and myricetin) varied from 2.7 to $5.1 \mathrm{mg} \mathrm{L}^{-1}$, values lower than those mentioned in the literature for grape juices (Talcott \& Lee, 2002). Lima et al. (2014) also mentioned low values of flavanols in grape juice produced by the varieties Isabel Precoce and BRS Cora planted in VSF.

For the stilbene trans-resveratrol no significant difference was observed among the juices from different maceration conditions, the values varied from 0.67 to $0.90 \mathrm{mg} \mathrm{L}^{-1}$. The values of trans-resveratrol obtained here can be considered high, since several authors mentioned concentrations of this compound in grape juices from different cultivars, region of origin and process of elaboration varying from 0.00 to $0.44 \mathrm{mg} \mathrm{L}^{-1}$ (Dani et al., 2007; Leblanc et al., 2008; Natividade et al., 2013; Sautter et al., 2005).

The values of trans-resveratrol for the juices elaborated in this work can be associated to combined factors as management of vines, climatic conditions of the region and process used, which may have favored the extraction of stilbene (Lima et al., 2014).

\subsection{Profile of anthocyanins of grape juices}

The concentration of total monomeric anthocyanins in the juices did not present significant differences $(p<0.05)$ among the maceration treatments used in this work, the mean values varied from 103 to $155 \mathrm{mg} \mathrm{L}^{-1}$. The total sum of anthocyanins quantified by HPLC varied from 25.2 to $44.1 \mathrm{mg} \mathrm{L}^{-1}$ for the juices obtained from different conditions of maceration, mainly malvidin 3-glucoside with mean values among 7.1 and $11.2 \mathrm{mg} \mathrm{L}^{-1}$, followed in descending order by cyanidin 3-glucoside (5.2$\left.8.0 \mathrm{mg} \mathrm{L}^{-1}\right)$, malvidin 3,5 diglucoside $\left(5.2-6.6 \mathrm{mg} \mathrm{L}^{-1}\right)$, cyanidin 3,5 diglucoside (3.9-5.7 $\mathrm{mg} \mathrm{L}^{-1}$ ), delphinidin 3-glucoside (1.2$\left.6.0 \mathrm{mg} \mathrm{L}^{-1}\right)$, pelargonidin 3-glucoside $\left(0.4-3.9 \mathrm{mg} \mathrm{L}^{-1}\right)$ and peonidin 3-glucoside (2.0-3.1 $\left.\mathrm{mg} \mathrm{L}^{-1}\right)$, where a homogeneous distribution of anthocyanins was observed in the grape juices.

The variation of total anthocyanins quantified by HPLC at 50 and $60{ }^{\circ} \mathrm{C}$ is associated with the high variance in the treatments, observed by high standard deviation in treatments T50E0 and T60E3, explained by the heterogeneity of the material (grape fruit) as a result of ambient/production factors, since each repetition was original of a tank containing $3000 \mathrm{~kg}$ of grape from different lotes.

The variety Isabel Precoce is the main cultivar used for the formulation of the juices, since the variety BRS Cora was used to improve the color of commercial grape juice. The profile of anthocyanins obtained for the grape juices produced with these two cultivars in different conditions of maceration are in accordance with previous works related to the profile of this compound in V. labrusca grape juices (Lima et al., 2014; Natividade et al., 2013). Also the total monomeric anthocyanins content are in accordance with results from the literature for artisanal and commercial Brazilian grape juices, which varied from 25.6 to $450.4 \mathrm{mg} \mathrm{L}^{-1}$, and commercial Spanish grape juices with values from 129 to $535 \mathrm{mg} \mathrm{L}^{-1}$ (Burin et al., 2010; Lima et al., 2014; Malacrida \& Motta, 2005; Moreno-Montoro et al., 2015; Toaldo et al., 2014), but lower than the values mentioned by lyer et al. (2010) for grape juices from "Concord" cultivar ( $850 \mathrm{mg} \mathrm{L}^{-1}$ ) elaborated in industrial condition by HP process in the United States of America, maceration at $60{ }^{\circ} \mathrm{C}$ 


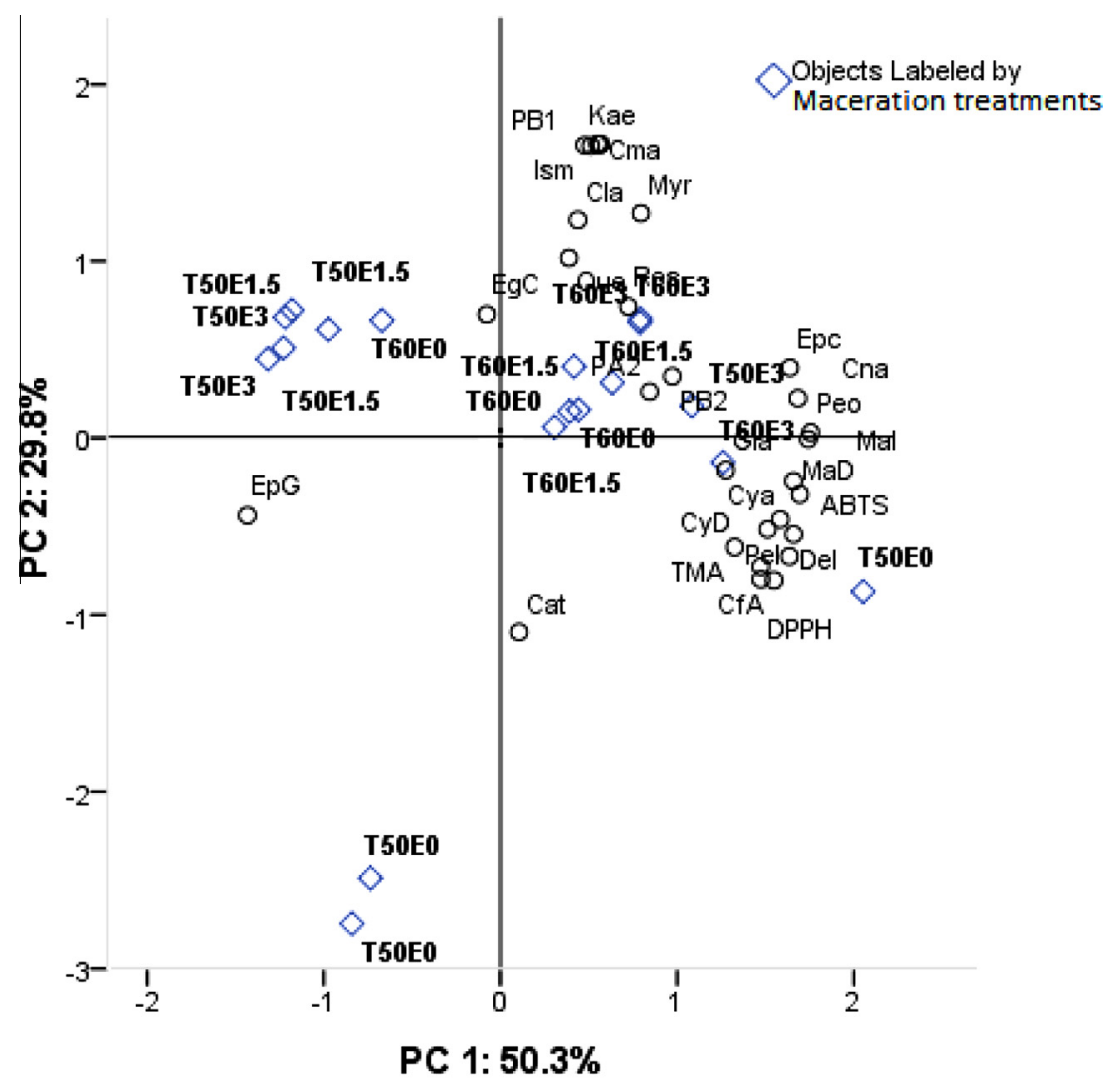

Variable Principal Normalization.

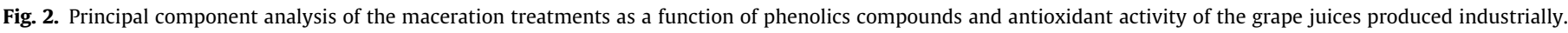

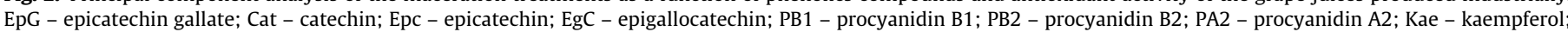

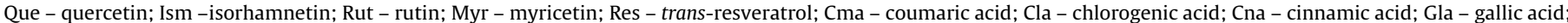

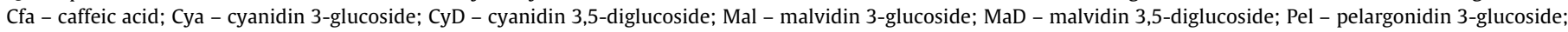

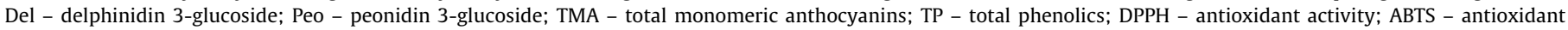
activity.

during $30 \mathrm{~min}$ and addition of $3.5 \mathrm{~mL}$ of enzymatic pool per $100 \mathrm{~kg}$ of grape fruit.

The sum of anthocyanins quantified by HPLC in the juices produced here under different conditions of maceration are also in accordance with the data obtained by Capanoglu, Vos, Hall, Boyacioglu, and Beekwilder (2012) for grape juices pasteurized and clarified at industrial scale in Turkey (maceration at 40 and $50{ }^{\circ} \mathrm{C}$, during $30-45 \mathrm{~min}$ with the addition of pectinase).

Several studies have also shown that the concentration and profile of anthocyanins vary as a function of processing techniques and cultivars used (Dani et al., 2007; Lima et al., 2014; Talcott \& Lee, 2002; Toaldo et al., 2014) and steps as pasteurization and treatments of clarification, centrifugation and filtration result in decrease in the concentration of anthocyanins of juices produced in industrial scale (Capanoglu et al., 2012).

\subsection{Content of phenolic acids of grape juices}

The sum of total phenolic acids quantified in this work varied from 22.4 to $29.2 \mathrm{mg} \mathrm{L}^{-1}$ for the different formulations. No significant difference $(p<0.05)$ was observed for the phenolic acids identified. The major compound was caffeic acid (values from 15.3 to $\left.17.9 \mathrm{mg} \mathrm{L}^{-1}\right)$, followed by gallic ( 2.2 to $3.4 \mathrm{mg} \mathrm{L}^{-1}$ ), cinnamic ( 0.5 to $2.0 \mathrm{mg} \mathrm{L}^{-1}$ ), chlorogenic (1.8 to $3.2 \mathrm{mg} \mathrm{L}^{-1}$ ) and p-coumaric ( 1.1 to $1.7 \mathrm{mg} \mathrm{L}^{-1}$ ) acids. The values obtained for these last acids are in accordance with those mentioned by other authors (Moreno-Montoro et al., 2015; Natividade et al., 2013; Stalmach, Edwards, Wightman, \& Crozier, 2011) however for caffeic acid the values obtained here were higher than those on the literature. Mudnic et al. (2010) observed that the phenolic acids present a high antioxidant activity, suggesting an effective contribution of caffeic acid to this bioactive property observed on the $V$. labrusca grape juice produced in this work.

\subsection{In vitro antioxidant activity of grape juices}

The antioxidant activity of grape juices produced at different conditions of maceration is presented in Fig. 1. The antioxidant activity of juices (AOX) was expressed as equivalents $(\mathrm{mM})$ of Trolox per liter of juice ( $\left.\mathrm{mM} \mathrm{TEAC} \mathrm{L}^{-1}\right)$. The values of AOX varied from 23.20 to $31.38 \mathrm{mM}$ by the $\mathrm{DPPH}$ and from 26.20 to $34.17 \mathrm{mM}$ by the ABTS methods. These results are in agreement with the AOX values of Brazilian grape juices, which present mean values from 2.12 to $54.6 \mathrm{mM} \mathrm{TEAC} \mathrm{L}^{-1}$ (Burin et al., 2010; Lima et al., 2014) and Spanish grape juices, with mean values from 15.1 to $27.1 \mathrm{mM} \mathrm{TEAC} \mathrm{L}^{-1}$ (Moreno-Montoro et al., 2015).

In a general way, the AOX values increased with the increase of enzyme dose and temperature, possibly due to the higher extraction of antioxidant phenolic compounds, except for treatment T50E0, which presented high activity using lower temperature and without addition of enzyme. This fact can be associated to higher concentration of phenolics in grapes of lotes destined to the elaboration of juices.

Finally, the antioxidant activity determined for the juices produced here is considered high and can be related to the characteristics of the viticulture in the region of origin of grapes (Lima et al., 
2014). In spite of the high values of AOX found here, no significant difference $(p<0.05)$ was observed for the different juices obtained for each different process.

\subsection{Principal Components Analysis (PCA)}

The Principal Components Analysis (PCA) was applied in the different maceration treatments as a function of phenolic compounds and antioxidant activity, resulting in 28 principal components. The components 1 and 2 (PC1 and PC2, respectively) explained $80.1 \%$ of the variance of the experiment, PC1 explained $50.3 \%$ and PC2 $29.8 \%$. The factor af analysis showed that the variables with higher contribution for the separation of the maceration treatments on PC1 with loading $>0.70$ were total phenolics (TP), total monomeric anthocyanins (TMA), antioxidant activity (DPPH and ABTS), epicatechin (Epc), epicatechin gallate (loading negative), gallic acid (Gla), caffeic acid (Cfa), cinnamic acid (Cna), pelargonidin 3-glucoside (Pel), cyanidin 3-glucoside (Cya), cyanidin 3,5-diglucoside (CyD), malvidin 3-glucoside (Mal), malvidin 3,5-diglucoside (MaD), delphinidin 3-glucoside (Del) and peonidin 3-glucoside (Peo). For PC2 the variables that more contributed on the separation (loading $>0.70$ ) were: procyanidin B1 (PB1), p-coumaric acid (Cma), kaempferol (Kae), isorhamnetin (Ism) and rutin (Rut).

The components PC1 and PC2 separated the treatments of maceration in distinct groups. The component 1 (PC1) with a greater importance on explained variance $(50.3 \%)$ separated the maceration treatments in two groups, the processes at $50{ }^{\circ} \mathrm{C}$ (T50E0, $\mathrm{T} 50 \mathrm{E} 1.5$ and T50E3) and at $60{ }^{\circ} \mathrm{C}$ (T60E0; T60E1.5 and T60E3), influenced mainly by the positive correlations among the treatments at $60^{\circ} \mathrm{C}$ with TP, TMA, DPPH, ABTS, Epc, Gla, Cfa, Cna, Pel, Cya, CyD, Mal, MaD, Del, Pel and Peo. The component 2 (PC2) separated the treatments in one group, (T60E0, T50E1.5; T50E3, T60E1.5 and T60E3), influenced by the positive correlations among the treatments T60E0, T50E1.5, T50E3, T60E1.5 and T60E3 with PB1, Cma, Kae, Ism and Rut. Based on the separations obtained in PC1 and PC2 it was evidenced that the increase on the temperature was the factor that more contributed to a higher extraction of phenolic compounds, mainly anthocyanins. The use of a enzymatic pool for the maceration was the factor that most influenced the increase of concentrations of procyanidin B1, p-coumaric acid, kaempferol, quercetin, isorhamnetin and rutin. The combination of temperature of $60^{\circ} \mathrm{C}$ with the use of enzymatic pool evidenced a higher extraction of almost all quantified phenolic compounds, except for epicatechin gallate, and on the increase of antioxidant activity of the juice. Fig. 2 presents the principal component analysis of the maceration treatments as a function of phenolic compounds and antioxidant activity of the grape juices produced industrially.

Cabrera et al. (2009) showed that an increase on temperature of the maceration process from 60 to $80^{\circ} \mathrm{C}$ contributed to an increase of total phenolics, total monomeric anthocyanins and antioxidant activity of grape juices, corroborating the results obtained here. Leblanc et al. (2008) observed that the HP process combined with the use of pectinase on maceration step also enhanced the stilbenes concentrations, concluding that the use of heat was the main factor related to the increase of concentration of this class of compounds.

\section{Conclusions}

The process used for production of grape juice presented high yield without the pressing the fruit. The temperature of $60{ }^{\circ} \mathrm{C}$ with addition of pectinase resulted in an increase on the yield and decrease of turbidity. The use of enzyme decreased the concentration of catechins and increased the content of procyanidin B1 and
B2. The temperature of maceration of $60^{\circ} \mathrm{C}$ contributed to the higher extraction of phenolic compounds, mainly anthocyanins. The combination of temperature $60^{\circ} \mathrm{C}$ with the use of enzymatic poll resulted in higher extraction of all analyzed phenolic compounds, increase of almost all organic acids and decrease of acetic acid content. The antioxidant activity was high and can be related to the contents of anthocyanins, total phenolics, catechins, caffeic acid, cinnamic acid and gallic acid. Among the quantified bioactive compounds, the caffeic acid, procyanidin B1 and trans-resveratrol presented higher contents compared to juices of other regions. The analysis of principal components was efficient to show the effect of maceration treatments, giving evidence of positive effect of temperature and pectinases addition on the extraction of desirable grape compounds. A high quality juice was obtained in industrial scale, contributing to the process development taking into account the bioactive properties of the product.

\section{Acknowledgments}

The authors would like to acknowledge the Fundação de Amparo à Ciência e Tecnologia do Estado de Pernambuco FACEPE for granting a scholarship and financial support (Projeto APQ-0962-5.07/10). They are also grateful to The Empresa Brasileira de Frutas Tropicais (EBFT/ASA) for providing the infrastructure, in-line process and raw materials used in the preparation of the grape juices.

\section{References}

Arnous, A., \& Meyer, A. S. (2010). Discriminated release of phenolic substances from red wine grape skins (Vitis vinifera L.) by multicomponent enzymes treatment. Biochemical Engineering Journal, 49, 68-77.

Brazil. Instrução Normativa $n^{\circ} 01$, de 07 de janeiro de 2000. Regulamento técnico geral para fixação dos padrões de identidade e qualidade para polpa de fruta. Diário Oficial da República Federativa do Brazil, Brasília, DF, 10 jan. 2000, Seção 1 , p. $54-58$.

Burin, V. M., Falcão, L. D., Gonzaga, L. V., Fett, R., Rosier, J. P., \& Bordignon-Luiz, M. T. (2010). Colour, phenolic content and antioxidant activity of grape juice. Ciência e Tecnologia de Alimentos, 30(4), 1027-1032.

Cabrera, S. G., Jang, J. I. H., Kim, S. T., Lee, Y. R., Lee, H. J., Chung, H. S., \& Moon, K. D. (2009). Effects of processing time and temperature on the quality components of Campbell grape juice. Journal of Food Processing and Preservation, 33, 347-360.

Capanoglu, E., Vos, R. C. H., Hall, R. D., Boyacioglu, D., \& Beekwilder, J. (2012). Changes in polyphenol content during production of grape juice concentrate. Food Chemistry, 139, 521-526.

Cascales, I. R., Garcia, J. M. R., Roca, J. M. L., \& Plaza, E. G. (2012). The effect of a commercial pectinolytic enzyme on grape skin cell wall degradation and colour evolution during the maceration process. Food Chemistry, 130, 626-631.

Dani, C., Oliboni, L. S., Vanderlinde, R., Bonatto, D., Salvador, M., \& Henriques, J. A. P. (2007). Phenolic content and antioxidant activities of white and purple juices manufactured with organically- or conventionally-produced grapes. Food and Chemical Toxicology, 45, 2574-2580.

Dávalos, A., Bartolome, B., \& Gómez-Cordovés, C. (2005). Antioxidant properties of commercial grape juices and vinegars. Food Chemistry, 93, 325-330.

Fuleki, T., \& Ricardo-da-Silva, J. M. (2003). Effects of cultivar and processing method on the contents of catechins and procyanidins in grape juice. Journal of Agricultural and Food Chemistry, 51, 640-646.

Giusti, M. M., \& Wrolstad, R. E. (2001). Characterization and measurement of anthocyanins by UV-Visible spectroscopy. In Current protocols in food analytical chemistry. New York, USA: John Wiley and Sons Inc..

Gomes, E., Guez, M. A. U., Martin, N., \& Silva, R. (2007). Enzimas termoestáveis: fontes, produção e aplicação industrial. Quimica Nova, 30(1), 136-145.

Iyer, M. M., Sacks, G. L., \& Padilla-Zakour, O. I. (2010). Impact of harvesting and processing conditions on green leaf volatile development and phenolics in concord grape juice. Journal of Food Science, 75(3), 297-304.

Kim, Y. K., Guo, Q., \& Packer, L. (2002). Free radical scavenging activity of red ginseng aqueous extracts. Toxicology, 172, 149-156.

Krikorian, R., Boespflug, E. L., Fleck, D. E., Stein, A. L., Wightman, J. D., Shidler, M. D. \& Hossieny, S. S. (2012). Concord grape juice supplementation and neurocognitive function in human aging. Journal of Agricultural and Food Chemistry, 60, 5736-5742.

Landbo, A.-K., \& Meyer, A. S. (2004). Effects of different enzymatic maceration treatments on enhancement of anthocyanins and other phenolics in black currant juice. Innovative Food Science and Emerging Technologies, 5, 503-513.

Leblanc, M. R., Johnson, C. E., \& Wilson, P. W. (2008). Influence of pressing method on juice stilbene content in Muscadine and Bunch Grapes. Journal of Food Science, 73, 1-4. 
Lima, M. D. S., Silani, I. S. V., Toaldo, I. M., Corrêa, L. C., Biasoto, A. C. T., Pereira, G. E., Bordignon-Luiz, M. T., \& Ninow, J. L. (2014). Phenolic compounds, organic acids and antioxidant activity of grape juices produced from new Brazilian varieties planted in the Northeast Region of Brazil. Food Chemistry, 161, 94-103.

Malacrida, C. R., \& Motta, S. (2005). Compostos fenólicos totais e antocianinas em suco de uva. Ciência e Tecnologia de Alimentos, 25, 659-664.

Mojsov, K., Ziberoski, J., \& Bozinovic, Z. (2011). The effect of pectinolytic enzyme treatments on red grapes mash of Vranec on grape juice yields. International Cross-Industry Journal, 7(1), 84-86.

Moreno-Montoro, M., Olalla-Herrera, M., Gimenez-Martinez, R., Navarro-Alarcon, M., \& Rufián-Henares, J. A. (2015). Phenolic compounds and antioxidant activity of Spanish commercial grape juices. Journal of Food Composition and Analysis, 38, 19-26.

Morris, J. R. (1998). Factors influencing grape juice quality. HortTechnology, 8(4), 471-478.

Morris, J. R., \& Striegler, K. R. (2005). Processing fruits: Science and technology (2nd ed.). Boca Raton, Fla.: CRC Press.

Mudnic, I., Modun, D., Rastija, V., Vukovic, J., Brizic, I., Katalinic, V., Kozina, B., MedicSaric, M., \& Boban, M. (2010). Antioxidative and vasodilatory effects of phenolic acids in wine. Food Chemistry, 119, 1205-1210.

Muselík, J., García-Alonso, M., Martín-López, M. P., Žemlička, M., \& Rivas-Gonzalo, J. C. (2007). Measurement of antioxidant activity of wine catechins, procyanidins, anthocyanins and pyranoanthocyanins. International Journal of Molecular Sciences, 8, 797-809.

Natividade, M. M. P., Corrêa, L. C., Souza, S. V. C., Pereira, G. E., \& Lima, L. C. O. (2013). Simultaneous analysis of 25 phenolic compounds in grape juice for HPLC: Method validation and characterization of São Francisco Valley samples. Microchemical Journal, 110, 665-674.

OIV - Organisation Internationale de la Vigne et du Vin (2011). Recueil des methods internationals d'analyse des vins et des mouts, edition 2011. 8th Assemblée Générale, 21 June 2010, Paris.

Re, R., Pellegrini, N., Proteggente, A., Pannala, A., Yang, M., \& Rice-Evans, C. (1999). Antioxidant activity applying an improved ABTS radical cation decolorization assay. Free Radical Biology E' Medicine, 26, 1231-1237.
Rizzon, L. A., \& Miele, A. (2012). Analytical characteristics and discrimination of Brazilian commercial grape juice, nectar, and beverage. Ciência e Tecnologia de Alimentos, 32, 93-97.

Rybka, A. C. P., Pereira, G. E., Biasoto, A. C. T., Corrêa, L. C. Development of methodology for the determination of organic acids in must, grape juice and wine by high performance liquid chromatography (HPLC). In 16th world congress of food science and technology: Addressing global food security and wellness through food science and technology, 2012, Foz do Iguaçu. Book of Abstracts, 2012. Available in: http://iufost.org.br/sites/iufost.org.br/files/anais/ 05609.pdf.

Sautter, C. K., Denardin, S., Alves, A. O., Mallmann, C. A., Penna, N. G., \& Hecktheuer L. H. (2005). Determinação de resveratrol em sucos de uva no Brazil. Ciência e Tecnologia de Alimentos, 25, 437-442.

Singleton, V. L., \& Rossi, J. A. (1965). Colorimetry of total phenolics with phosphomolybdic phosphotungstic acid reagents. American Journal of Enology and Viticulture, 16, 144-158.

Soyer, Y., Koca, N., \& Karadeniz, F. (2003). Organic acid profile of Turkish white grapes and grape juices. Journal of Food Composition and Analysis, 16, 629-636.

Stalmach, A., Edwards, C. A., Wightman, J. D. \& Crozier, A. (2011). Identification of (poly)phenolic compounds in Concord grape juice and their metabolites in human plasma and urine after juice consumption. Journal of Agricultural and Food Chemistry, 59, 9512-9522.

Talcott, S. T., \& Lee, J.-H. (2002). Ellagic acid and flavonoid antioxidant content of Muscadine wine and juice. Journal of Agricultural and Food Chemistry, 50 3186-3192.

Toaldo, I. M., Gois, J. S., Fogolari, O , Hamann, D., Borges, D. L. G. \& Bordignon-Luiz, M. T. (2014). Phytochemical polyphenol extraction and elemental composition of Vitis labrusca L. grape juices through optimization of pectinolytic activity Food and Bioprocess Technology, 7, 2581-2594.

Vauzour, D., Rodriguez-Mateos, A., Corona, G., Oruna-Concha, M. J., \& Spencer, J. P. E. (2010). Polyphenols and human health: Prevention of disease and mechanisms of action. Nutrients, 2, 1106-1131.

Xia, E-O., Deng, G. F., Guo, Y.J. \& Li, H.-B. (2010). Biological activities of polyphenols from grapes. International Journal of Molecular Sciences, 11 622-646. 